\title{
Extra-gastrointestinal stromal tumor of the pancreas: case report and review of the literature
}

\author{
Valentina Beltrame ${ }^{1}$, Mario Gruppo ${ }^{1}$, Davide Pastorelli ${ }^{2}$, Sara Pizzi ${ }^{3}$, Stefano Merigliano ${ }^{1}$ and Cosimo Sperti ${ }^{*}$
}

\begin{abstract}
Primary extra-gastrointestinal stromal tumor (EGISTs) arising in the pancreas is extremely rare: only 20 cases have previously been reported in the English literature from 2000 to 2013. We reported a case of EGIST of the pancreas in a 69-year-old woman who presented with abdominal pain and with a solid, heterogeneously enhancing neoplasm in the uncinate process of the pancreas, revealed preoperatively by an abdominal computed tomography scan. A diagnosis of neuroendocrine tumor was suggested. Positron emission tomography with 68Ga-DOTATOC did not show pathological accumulation of the tracer in the pancreas. The patient underwent enucleation, under ultrasonic guidance, of the pancreatic tumor that emerged to the surface of the pancreas. Histopathology and immunohistochemical examination confirmed the final diagnosis of EGIST of the pancreas (CD117+), with one mitosis per 50 high-power fields. Although rarely, GIST can involve the pancreas as a primary site, and this tumor should be considered in the differential diagnosis of pancreatic neoplasms.
\end{abstract}

Keywords: Differential diagnosis, Gastrointestinal stromal tumor, Pancreas, Pancreatectomy, Pancreatic neoplasms

\section{Background}

Gastrointestinal stromal tumors (GIST) are the most common mesenchymal tumors of the gastrointestinal tract, with an annual incidence of 10 to 20 per million [1]. GISTs are neoplasms arising from, or differentiating along, a line similar to the gastrointestinal pacemaker cells, the interstitial cells of Cajal (ICCs) [2-4]. ICCs form a network around the myenteric plexus and within the muscolaris propriae of the gastrointestinal wall. GISTs may occur in the entire length of gastrointestinal tract from the esophagus to the anus; however, the most common sites are stomach (60\%), small intestine (30\%), rectum (5\%), and esophagus $(<5 \%)$ [1]. Duodenal GISTs constitute 30\% of primary duodenal tumors and less than $5 \%$ of gastrointestinal stromal tumors [5-7]. Sometimes, these tumors may arise from the omentum, mesentery, gallbladder, and retroperitoneum, adjacent, but separate from the stomach and the intestine [8-10]; in this case the neoplasm is defined as 'extra-gastrointestinal stromal tumors' (EGISTs). EGISTs do not display connection to the wall or the serosal surface of the viscera. EGISTs arising in the pancreas are extremely rare, and only

\footnotetext{
* Correspondence: csperti@libero.it

'Department of Surgery, Oncology and Gastroenterology, 3rd Surgical Clinic, University of Padua, Giustiniani 2, 35128, Padua, Italy

Full list of author information is available at the end of the article
}

20 cases have been reported in the literature from 2000 to 2013 [11-31]. We present a new case of a pancreatic EGIST misinterpreted as non-functioning endocrine tumor, in a 69-year-old woman. A review of the literature is also included.

\section{Case presentation}

A 69-year-old woman presented in March 2013 with abdominal pain localized in the right hyphocondrium. There was no history of vomiting, gastrointestinal bleeding, jaundice, anorexia, or weight loss. Abdominal ultrasonography did not show pathologic features, but the pancreas was not clearly visualized. Contrast-enhanced computed tomography (CT) of the abdomen (Figure 1) revealed a solid, hypervascular nodule in the uncinate process of the pancreas, measuring $22 \times 15 \mathrm{~mm}$. The possibility of a neuroendocrine tumor was considered; therefore she underwent Gallium-68 somatostatin receptor positron emission tomography (PET) (68Ga-DOTATOC), without evidence of neoplasms with pathologic expression of somatostatin receptors. Routine laboratory investigations, exocrine and endocrine serum markers, and hormonal panel were within normal limits, except for CEA: $5.7 \mathrm{ug} / \mathrm{L}$ ( reference value $<5 \mathrm{ug} / \mathrm{L}$ ). Endoscopic ultrasound (EUS) confirmed a 2-cm hypoechoic tumor 


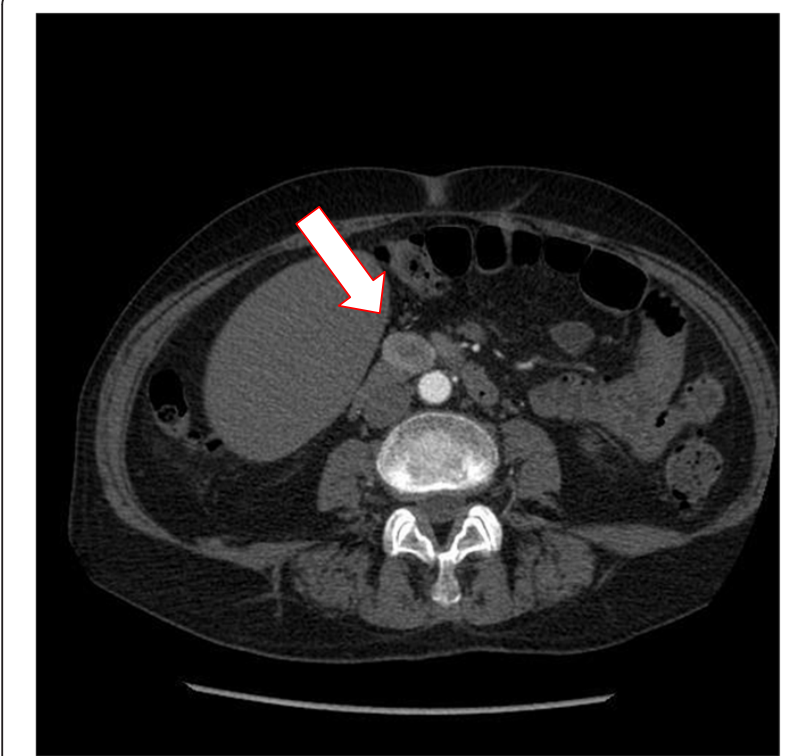

Figure 1 Abdominal CT scan showing a 2-cm, contrast-enhanced mass (arrow) in the uncinate process of the pancreas.

in the head of the pancreas; fine-needle aspiration of the lesion was not available at that moment. At laparotomy, in April 2013, a well-demarcated, red nodule was identified in the uncinate process of the pancreas; no attach with the duodenal wall was found. Intraoperative sonography showed that the 2-cm hypoechoic mass was separated from the main pancreatic duct. Careful enucleation of the tumor with Harmonic scalpel, under ultrasound guidance, was successfully performed. Pancreatic capsula was closed with interrupted, absorbable stitches. The postoperative course was uneventful, and the patient was discharged 7 days after surgery. Macroscopic examination showed a $2.4 \mathrm{~cm}$ well defined, ovoid mass. Microscopically, the tumor was composed of spindle cells, with focal atypia (Figure 2). The mitotic count was one mitoses/50 high power fields (HPFs). Immunohistochemical examination showed neoplastic cells diffusely positive for antibodies against CD 117 (Figure 3), focally positive for CD34 (Figure 4) and smooth muscle actin, while cells were negative for desmin. A diagnosis of pancreatic GIST with low risk of malignancy has been placed, pT2NOM0, stage I according to TNM (AJCC) classification [32]. On molecular genetic examination, deletion of three nucleotides in exon 11 of c-Kit was found. She did not receive any adjuvant therapy after surgery; 12 months later she is in good general condition and there is no evidence of recurrent disease.

\section{Discussion}

We reported a rare case of a primary pancreatic GIST: the small size, the well circumscribed margins of the lesion, and the contrast enhancement at CT examination

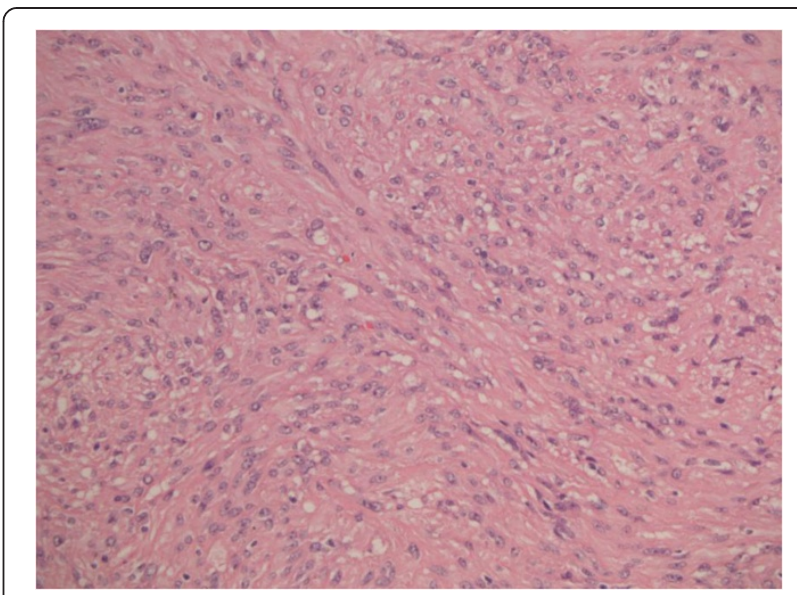

Figure 2 Stromal tumor composed of spindle and epithelioid cells with focal vacuolar (signet ring) change. (E \& E, 20x).

suggested a diagnosis of neuroendocrine tumor of the pancreas. GISTs reported outside the gastrointestinal tract as apparent primary tumors are defined as 'extra-gastrointestinal stromal tumors' (EGISTs). The concept of GIST has recently been established, due to the progress in immunohistochemical analyses. It is presumed that these tumors originate from the interstitial cells of Cajal (ICCs), pacemaker cells, which are present throughout the wall of the gastrointestinal tract and which regulate the motility. ICCs share many characteristics with EGISTs, including expression of CD117 and CD34 [2]. In fact, the most selective immunohistochemical markers differentiating GISTs from true smooth muscle tumors is the expression of the c-Kit receptor tyrosine kinase (CD117 antigen) in 95\% of GISTs. In 2004, Yamamoto et al. [31] reported that EGISTs show similar KIT mutations of typical GISTs suggesting that these tumors have a similar origin. However, at present the origin of EGISTs remains controversial. Some authors

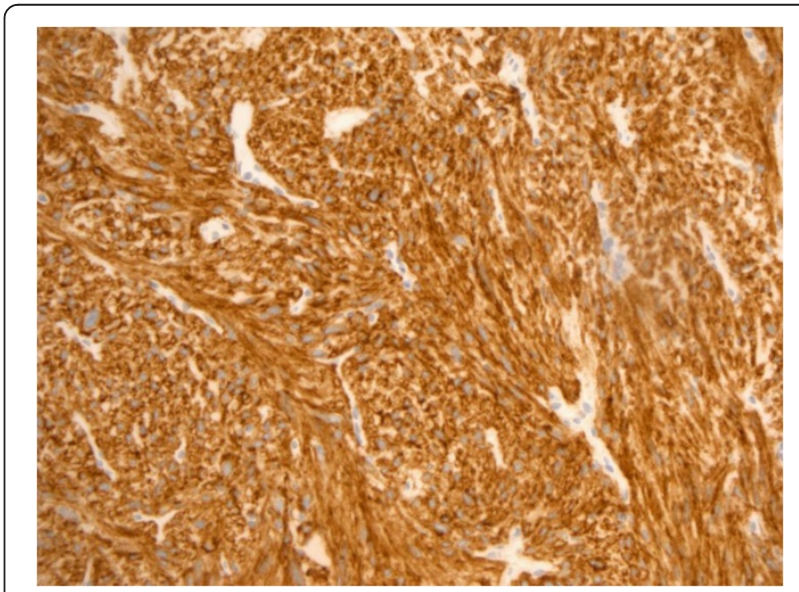

Figure 3 Immunostain for C-KIT: strong and diffuse cytoplasmic immunoreactivity. 


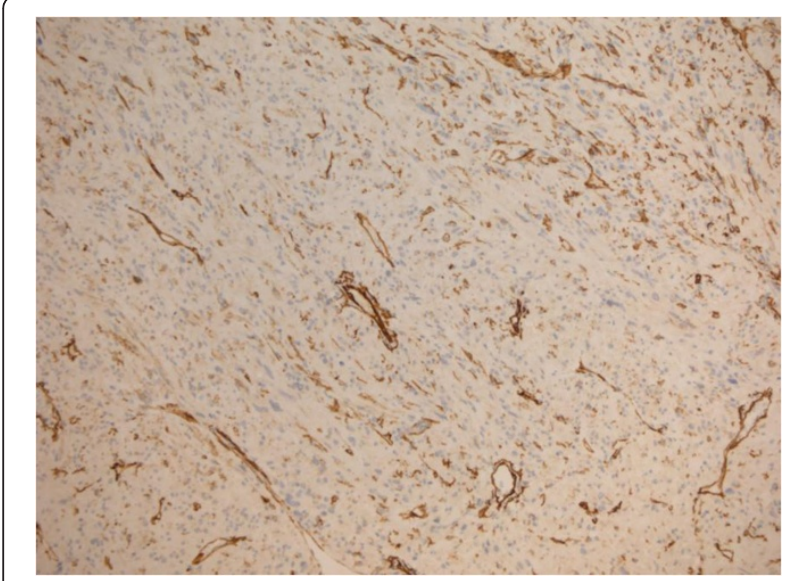

Figure 4 Immunostain for CD34: focal immunoreactivity.

believe that GISTs and EGISTs arise from the common precursor cell of ICCs and the smooth muscle cells of the gut, which may account for their growth within and outside the gastrointestinal tract [33]. Other, simpler, explanation suggests that EGISTs are in fact mural GISTs with extensive extramural growth, resulting in eventual loss of their connection with the gut wall [33].

Pancreatic GISTs are extremely rare. We collected only 21 cases (including our patient) from the English literature: their clinicopathologic features and outcomes are summarized in Table 1. The age of the patients ranges from 30 to 84 years, with a mean age of 55.0 years. The male:female ratio was 10:11. Ten of $21(48 \%)$ tumors occurred in the head of the pancreas, five in the tail (34\%), four involved both body and tail (19\%), and two occurred in the uncinate process (\%). EGIST rarely $(n=1.5 \%)$ involved the entire pancreas [24]. There is a great variation in size (range, 2.4 to $34 \mathrm{~cm}$ ). The mitotic count was $<5 / 50 \mathrm{HPFs}$ in eight cases (38\%) and $>10 / 50$ HPFs in four cases (19\%). Molecular biology of EGIST has been investigated in only two reports $[14,22]$ and in our patient: two exhibited deletion of base pairs in exon 11, and one showed DNA polymorphism of L862L in exon 18 of c-KIT gene [22]. All but one patient underwent surgery: one patient with metastatic disease died 5 days after admission without operation. One patient underwent palliative operation (cystojejunostomy) and the remaining 17 patients underwent pancreatic

Table 1 Clinicopathologic features, treatment, and outcome of EGISTs reported in the English literature

\begin{tabular}{|c|c|c|c|c|c|c|c|}
\hline Author & Year & Age (years) & Sex & Site/Treatment & Size $(\mathrm{cm})$ & $\begin{array}{l}\text { Mitotic count } \\
\text { (/50 HPF) }\end{array}$ & Follow-up, months \\
\hline Neto et al. [11] & 2004 & 67 & $\mathrm{~F}$ & Body and tail/DP + Imatinib & 20 & 120; CD117(+) CD34(+) & A, Relapse, 1 \\
\hline Yamaura et al. [12] & 2004 & 54 & $\mathrm{~F}$ & Tail/DP & 14 & Few; CD117(-) CD34(+) & A, NED, 30 \\
\hline Krska et al. [13] & 2005 & 38 & $\mathrm{~F}$ & Body and tail/DP & 17 & $1 ; C D 117(-)$ CD34(+) & A, NED, 30 \\
\hline Daum et al. [14] & 2005 & 70 & $\mathrm{~F}$ & Head/PD + Imatinib & 10 & 2; CD117(+) CD34(-) & A, NED, 6 \\
\hline Showalter et al. [15] & 2008 & 72 & $\mathrm{~F}$ & Tail/DP & 7 & 3; CD117(+) CD34(-) & A, NED, 27 \\
\hline Yan et al. [16] & 2008 & 47 & M & Uncinate process/NR & 2.4 & 3; CD117(+) CD34(-) & NA \\
\hline Yang et al. [17] & 2008 & 55 & M & Body and Tail/DP + Imatinib & NR & $\mathrm{NR} ; \mathrm{CD} 117(+) \mathrm{CD} 34(+)$ & Relapse, 24,- A, NED,41 \\
\hline Harindhanavudhi et al. [18] & 2008 & 63 & $\mathrm{~F}$ & $\begin{array}{l}\text { Body/Cystojejunostomy + } \\
\text { Imatinib }\end{array}$ & 16 & $<5 ; \mathrm{CD} 117(+) \mathrm{CD} 34(+)$ & NA \\
\hline Trablesi et al. [19] & 2009 & 52 & $\mathrm{~F}$ & Head/PD & 10.5 & 6; CD117(+) CD34(+) & A, NED, 10 \\
\hline Goh et al. [20] & 2009 & 58 & M & Head/PD & 9 & $>10 ;$ CD117(+); CD34 (-) & A, NED, 60 \\
\hline Padhi et al. [21] & 2010 & 42 & $\mathrm{~F}$ & Body and tail/DP & 35 & 6-8; CD117(+) CD34(+) & A, NED, 10 \\
\hline Saif et al. [22] & 2010 & 31 & M & Head/PD + Imatinib & 8 & 48; CD117(+) CD34(-) & A, Relapse, 9 \\
\hline Crisan et al. [23] & 2010 & 61 & M & Tail & 34 & NR & A, NED, 3 \\
\hline Joshi and Rustagi [24] & 2010 & 84 & M & Whole pancreas/NOP & 34 & $\mathrm{NR} ; \mathrm{CD} 117(+)$ CD34(+) & Dead day 5 of admission \\
\hline Rao et al. [25] & 2011 & 40 & M & $\begin{array}{l}\text { Head and body/PD + } \\
\text { Imatinib }\end{array}$ & 6.5 & 8-10; CD117(+) CD34(+) & Relapse, 24; A, NED 30 \\
\hline Cecka et al. [26] & 2011 & 74 & $\mathrm{~F}$ & Tail/DP & 11 & $<5 ;$ CD117(+)CD34(+) & A, NED, 66 \\
\hline Vij et al. [27] & 2011 & 35 & M & Head/PD + Imatinib & 6.5 & 12-15; CD117(+) CD34(-) & Relapse, 24; A, NED 48 \\
\hline Soufi et al. [28] & 2012 & 39 & M & Head/PD + Imatinib & 9 & 5; CD117(+) CD34(+) & A, NED, 24 \\
\hline Kim et al. [29] & 2012 & 55 & M & Tail/DP + Imatinib & 15.8 & 7; CD117(+) CD34(-) & $\mathrm{A}, \mathrm{NED}, 4$ \\
\hline Babu et al. [30] & 2012 & 55 & $\mathrm{~F}$ & Head/local resection & 5 & 6-8; CD117(+); CD34 (+) & A, NED, 11 \\
\hline Present case & 2013 & 63 & $\mathrm{~F}$ & Uncinate process/enucleation & 2.4 & $1 ; C D 117(+)$ & A, NED, 6 \\
\hline
\end{tabular}

$\mathrm{A}=$ alive; $\mathrm{DP}=$ distal pancreatectomy; $\mathrm{NA}=$ not available; $\mathrm{NED}=$ not evidence of disease; $\mathrm{NOP}=$ not operated; $\mathrm{NR}=$ not reported; $\mathrm{PD}=$ pancreaticoduodenectomy. 
resection (in 5 extended to adjacent organs), one had local resection, and one (our case) enucleation of the tumor. Follow-up was available in 19 cases. Disease recurrence following surgery was reported in five cases: three patients underwent re-resection and are alive and free after 30, 41, and 48 months, respectively. Overall, 18 patients are alive with a median survival time of 17.5 months (range, 1 to 66 months). Despite the limited number of cases and the short follow-up time, it appears that resection of pancreatic GISTS may offer a good prognosis, even in recurrent disease.

The clinical presentation of EGISTs is variable, depending on the location and size of the tumors. The tumor may even be found incidentally. The most frequent clinical symptoms are: abdominal pain, ileus, bleeding, anemia, and weight loss. Our patient presented with a small, solid, hyperintense lesion resembling a neuroendocrine tumor. A similar finding of small, solid tumor in the uncinate process of the pancreas was reported by Yan et al. [16] in a case of GIST diagnosed by EUS fine-needle aspiration (FNA): unfortunately, biopsy was not available for our patient. Interestingly, $50 \%(11 / 21)$ of the reported cases showed radiologic features of heterogeneously mass (necrotic areas) or solid-cystic appearance; thus, problems in differential diagnosis with cystic neoplasms of the pancreas could be arise. The accuracy of CT determination of the pathological diagnosis of a pancreatic cystic lesion is less than 50\% [34,35], but endoscopic ultrasound-guided FNA may be helpful for the diagnosis of pancreatic lesions [36]. The diagnosis of GIST is based on histological, immunohistochemical, and molecular features. Microscopically, this tumor, consisted of spindle cell and epithelioid cells. The cytologic differential diagnosis for these spindle cell proliferations includes leiomyoma, schwannoma, fibromatosis, inflammatory fibroid polyps, and gastrointestinal muscularis sampling [16]. Immunoistochemical positivity of CD117 confirms the diagnosis of GIST. GISTs exhibit a broad spectrum of clinical behaviors, with some lowrisk lesions remaining stable for years, while others progress rapidly to metastatic disease. Various parameters are proposed to predict the malignant potential of GIST, such as tumor size, mitotic activity, tumor location, nonradical resection, tumor rupture, peritoneal dissemination, metastasis, and invasion into adjacent organs. National Institute of Health (NIH) consensus criteria (Fletcher's criteria) [37] proposed risk stratification of tumor behavior into risk categories of very low, low, intermediate, and high risk of metastasis, based on its size and mitotic activity. Tumors larger than $10 \mathrm{~cm}$ in size and with more than $10 \mathrm{mi}-$ toses per $50 \mathrm{HPF}$ are at high risk of aggressive behavior $[33,37]$. Standard treatment for primary GIST is complete surgical resection with the aim to obtain negative microscopic margins of resection [13,38,39]. Lymphatic spread of GISTs is uncommon; therefore, a systematic lymph node dissection is not a standard surgical management. In our patient we performed a simple tumor's enucleation because of a preoperative diagnosis of neuroendocrine tumor. However, after discussion with oncologists, the small size of the lesion and the low-risk according to previously reported prognostic criteria [37], suggested that it was an adequate operation, as reported in a recent study [40]. The patient is alive and free of disease 1 year after operation. The surgical management may offer primary surgery at the time of diagnosis, neoadjuvant chemotherapy followed by surgery, adjuvant therapy after surgery, or debulking surgery in patients with metastatic or advanced disease. Observation only was recommended in case with R0 resection or low-risk GIST. In recent decades, medical therapy for GIST is improved (Imatinib, Sunitinib, Nilotinib, Sorafenib, Dovitinib, and so on) and consequently disease-free survival after surgery is also much improved: in fact, it is recommended in patients with R1 or R2 resection [41]. The results of some clinical trials [42-49] with targeted therapy of GIST are reported in Table 2. Obviously, data about targeted therapy for EGIST

Table 2 Selected agents investigated in the management of GIST

\begin{tabular}{|c|c|c|c|c|c|c|c|}
\hline Author & Year & Pts $(n)$ & Phase study & Treatment & End point & Outcome (\% or median) & $P$ value \\
\hline Demetri et al. [42] & 2002 & 147 & $\|$ & Imatinib & OR & $81.6 \%$ & \\
\hline Demetri GD et al. [43] & 2006 & 312 & III & Sunitinib/placebo & TTP & 27.3 vs. 5.4 weeks & $<0.0001$ \\
\hline \multirow[t]{2}{*}{ Blanke et al. [44] } & 2008 & 746 & III & Imatinib 400 mg/ & PFS & 18 vs. 20 months & 0.13 \\
\hline & & & & Imatinib 800 mg & OS & 55 vs. 51 months & 0.83 \\
\hline De Matteo et al. [45] & 2009 & 713 & III & Imatinib/placebo & PFS & $98 \%$ vs. $83 \%$ & $<0.0001$ \\
\hline Dubreuil et al. [46] & 2009 & 30 & $\|$ & Masitinib & PFS & 165.2 weeks & \\
\hline Sawaki et al. [47] & 2011 & 35 & $\|$ & Nilotinib & PFS & 16 weeks & \\
\hline \multirow[t]{2}{*}{ Park et al. [48] } & 2011 & 31 & $\|$ & Sorafenib & PFS & 4.9 months & \\
\hline & & & & & OS & 9.7 months & \\
\hline \multirow[t]{2}{*}{ Joensuu et al. [49] } & 2012 & 400 & III & Imatinib $12 \mathrm{mo} / 36 \mathrm{mo}$ & RFS \& OS & $65.6 \%$ vs. $47.9 \%$ & $<0.0001$ \\
\hline & & & & & & $92.0 \%$ vs. $81.7 \%$ & 0.019 \\
\hline
\end{tabular}


are limited. In the review of the literature, among 19 highrisk EGISTs, only nine cases (47\%) received adjuvant Imatinib therapy (Table 1).

\section{Conclusion}

In conclusion, we report a new case of EGIST arising from the pancreas, misinterpreted as neuroendocrine tumor. Despite its rarity, GIST should be kept in mind in the differential diagnosis of primary tumors of the pancreas, especially when a hypervascular lesion, solid or cystic, is lacking somatostatin receptors at PET examination. Radical resection of pancreatic GISTs is the treatment of choice, and repeat surgery for recurrence may offer a prolonged survival.

\section{Consent}

Written informed consent was obtained from the patient for publication of this case report and any accompanying image. A copy of the written consent is available for review by the Editor-in-Chief of this Journal.

\section{Competing interests}

The authors declare that they have no competing interests.

\section{Authors' contributions}

VB and CS conceived the study, carried out the literature search, and drafted the manuscript; MG and DP helped in management of the patient; SP carried out the pathologic diagnosis and immunoassays; SM made critical revisions and supervision. All authors read and approved the final manuscript.

\section{Acknowledgment}

We thank Ms Flavia Trabuio for her excellent help in the preparation of the manuscript.

\section{Author details}

'Department of Surgery, Oncology and Gastroenterology, 3rd Surgical Clinic, University of Padua, Giustiniani 2, 35128, Padua, Italy. ${ }^{2}$ Department of Oncology, Rare Tumors Unit, Veneto Institute of Oncology, Padua, Italy. ${ }^{3}$ Department of Pathology, University of Padua, Padua, Italy

Received: 9 September 2013 Accepted: 7 April 2014

Published: 23 April 2014

\section{References}

1. Beham AW, Scheefer IM, Schuler P, Cameron S, Ghadimi BM: Gastrointestinal stromal tumors. Int J Colorectal Dis 2012, 27:689-700

2. Kindblom L-G, Remotti HE, Aldenborg F, Meis-Kindblom JM: Gastrointestinal pacemaker cell tumor (GIPACT): gastrointestinal stromal tumors show phenotypic characteristics of the interstitial cell of Cajal. Am J Pathol 1998, 152:1259-1269.

3. Sircar K, Hewlett BR, Huizinga JD, Chorneyko K, Berezin I, Ridell RH: Interstitial cell of Cajal as precursor of gastrointestinal stromal tumors. Am J Surg Pathol 1999, 23:377-389.

4. Robinson TL, Sircar K, Hewlett BR, Chorneyko K, Riddel RH, Huizinga JD: Gastrointestinal stromal tumors may originate from a subset of CD34positiva interstitial cells of Cajal. Am J Pathol 2000, 156:1157-1163.

5. Beham A, Schaefer IM, Cameron S, von Hammerstein K, Fuzesi L, Ramadori G, Ghadimi MB: Duodenal GIST: a single center experience. Int I Colorectal Dis 2013, 28:581-590.

6. Buchs NC, Bucher P, Gervaz P, Ostermann S, Pugin F, Morel P: Segmental duodenectomy for gastrointestinal tumor stromal tumor of the duodenum. World J Gastroenterol 2010, 16:2788-2792.

7. Miettinen M, Kopczynski J, Makhlouf HR, Sarlomo-Rikala M, Gyorffy H, Burke A, Sobin LH, Lasota J: Gastrointestinal stromal tumors, intramural leiomyomas, and leiomyosarcomas in the duodenum: a clinicopathologic, immunohistochemical, and molecular genetic study of 167 cases. Am J Surg Pathol 2003, 27:625-631.

8. Reith JD, Goldblum GR, Lyles RH, Weiss SW: Extragastrintestinal (soft tissue) stromal tunor s: an analysis of 48 cases with emphasis on histologic predictors of outcome. Mod Pathol 2000, 13:577-585.

9. Miettinen M, Lasota J: Gastrointestinal stromal tumors: pathology and prognosis at different sites. Semin Diagn Pathol 2006, 23:70-83.

10. Miettinen M, Monihan JM, Sarlomo-Rikala M, Kovatich AJ, Carr NJ, Emory TS, Sobin LH: Gastrointestinal stromal tumors/smooth muscle tumors (GISTs) primary in the omentum and mesentery: clinicopathologic and immunoistochemical study of 26 cases. Am J Surg Pathol 1999, 23:1109-1118.

11. Neto MR, Machuca TN, Pinho RV, Yuasa LD, Bleggi-Torres LF: Gastrointestinal stromal tumor: report of two unusual cases. Virchows Arch 2004, 444:594-596.

12. Yamura K, Kato K, Mijazawa M, Haba Y, Muramatsu A, Miyata K, Koide N: Stromal tumor of the pancreas with expression of $\mathrm{C}$-kit protein: report of a case. J Gastrointestinal Hepatol 2004, 19:467-470.

13. Krska Z, Peskovà M, Povysil C, Horejs J, Sedlàckovà E, Kudrnovà Z: GIST of pancreas. Praque Med Rep 2005, 106:201-208.

14. Daum O, Klecka J, Ferda J, Treska V, Vanecek T, Sima R, Mukensnabi P, Michal M: Gastrointestinal stromal tumor of the pancreas: Case report with documentation of KIT gene mutation. Virchows Arch 2005, 446:470-472.

15. Showalter SL, Loyd JM, Glassman DT, Berger AC: Extra-intestinal stromal tumor of the pancreas: case report and a review of the literature. Arch Surg 2008, 143:305-308.

16. Yan BM, Pai RK, Dam JV: Diagnosis of pancreatic gastrointestinal stromal tumor by EUS guided FNA. JOP 2008, 9:192-196.

17. Yang F, Jin C, Fu D, Ni Q: Extra-gastrointestinal stromal tumor of the pancreas: Clinical characteristics, diagnosis, treatment, and outcome. J Surg Oncol 2011, 103:739-740.

18. Harindhanavdhi T, Tanawuttiwat T, Pyle J, Sillva R: Extra-gastrointestinal stromal tumor presenting as hemorrhagic pancreatic cyst diagnosed by EUS-FNA. JOP 2009, 10:189-191.

19. Trabelsi A, Yacoub-Abid LB, Mtimed A, Ben Abdelkrim S, Hammedi F, Ben Ali A Mokni M: Gastrointestinal stromal tumor of the pancreas. A case report and review of the literature. North Am J Med Sci 2009, 1:234-236.

20. Goh BK, Kesavan SM, Wonk WK: An unusual cause of pancreatic head tumor. Gastroenterology 2009, 137:e5-e6.

21. Padhi S, Kongara R, Uppin MS, Prayaga AK, Challa S, Nagari B, Regulagadda SA: Extra-gastrointestinal stromal tumors arising in the pancreas: a case report with a review of the literature. JOP 2010, 11:244-248.

22. Saif MW, Hotchikiss S, Kaley K: Gastrointestinal stromal tumors of the pancreas. JOP 2010, 11:405-406.

23. Crisan A, Nicoara E, Cucui V, Cornea G, Laza R: Prolonged fever associated with gastrointestinal stromal tumor-case report. J Exp Med Surg Res 2010, 17:219-224.

24. Joshi J, Rustagi T: Pancreatic extra-gastrointestinal stromal tumor: an unusual presentation of a rare diagnosis. Gastrointest Cancer Res 2010, Suppl 1:S29-S30

25. Rao RW, Vij M, Singla N, Kumar A: Malignant pancreatic extragastrointestinal stromal tumor diagnosed by ultrasound fine needle aspiration cytology. A case report with a review of literature. JOP 2011, 12:283-286

26. Cecka F, John B, Ferko A, Subrt Z, Nioliv DH, Tycova V: Long term survival of a patient after resection of gastrointestinal stromal tumor arising from the pancreas. Hepatobiliry Pancreat Dis Int 2011, 10:330-332.

27. Vij M, Agrawal V, Pandey R: Malignant extra-gastrointestinal stromal tumor of the pancreas. A case report and review of literature. JOP 2011, 12:200-204.

28. Soufi M, Bouziane M, Massrouri R, Chad B: Pancreatic GIST with pancreas divisum: a new entity. Int J SurgCase Rep 2013, 4:68-71.

29. Kim HH, Koh YS, Park EK, Seoung JS, Hur YH, Kim JC, Cho CK: Primary extragastrointestinal stromal tumor arising in the pancreas: report of a case. Surg Today 2012, 42:386-390.

30. Babu SR, Kumari S, Zhang Y, Su A, Wang W, Tian B: Extragastrointestinal stromal tumor arising in the pancreas: a case report and literature review. J Gastroenterol Hepatol Res 2012, 1:80-83.

31. Yamamoto H, Oda Y, Kawaquchi K, Nakamura N, Takahira T, Tamiya S, Saito T, Oshiro Y, Ohta M, Yao T, Tsuneyoshi M: C-kit and PDGFRA mutations in extragastrointestinal stromal tumor (gastrointestinal stromal tumor of the soft tissue). Am J Surg Pathol 2004, 28:479-488.

32. Sobin LH, Gospodarovicz MK, Wittekind C: UICC TNM Clasification of malignant tumours. 7th edition. Hoboken, NJ: Wiley-Blackwell; 2009. 
33. Agaimy A: Gastrointestinal stromal tumors (GIST) from risk stratification system to the new TNM proposal: more question and answers? A review emphasizing the need for a standardization GIST reporting. Int J Clin Exp Pathol 2010, 3:461-471.

34. Visser BC, Yeh BM, Qayyum A, Way LW, McCulloch CE, Coakley FV: Characterization of cystic pancreatic masses: relative accuracy of CT and MRI AJR. Am J Roentgenol 2007, 189:648-656.

35. Lee HJ, Kim MJ, Choi JY, Hong HS, Kim KA: Relative accuracy of CT and $\mathrm{MRI}$ in the differentiation of benign from malignant pancreatic cystic lesions. Clin Radiol 2011, 66:315-321.

36. Akahoshi K, Sumida Y, Matsui N, Oya M, Akinaga R, Kubokawa M, Motomura Y, Honda K, Watanabe M, Nagaie T: Preoperative diagnosis of gastrointestinal stromal tumour by endoscopic ultrasound-guided fine needle aspiration. World J Gastroenterol 2007, 13:2077-2082.

37. Fletcher CD, Berman JJ, Corless C, Gorstein F, Lasota J, Longley BJ, Miettinen M, O'Leary TJ, Remotti H, Rubin BP, Shmookler B, Sobin LH, Weiss SW: Diagnosis of gastrointestinal stromal tumors; a consensus approach. Hum Pathol 2002, 33:459-465.

38. Gervaz $\mathrm{P}$, Huber $\mathrm{O}$, Morel P: Surgical management of gastrointestinal stromal tumors. Br J Surg 2009, 96:567-578.

39. Golpadas RR, Toedter $\sqcup$, Dorman SA, Rohatgi C: Gastrointestinal stromal tumo of the pancreatoduodenal complex: a detailed review and development of new prognostic scoring system. Cancer Ther 2008, 6:577-596.

40. Zhou B, Zhang M, Wu J, Yan S, Zhou J, Zheng S:

Pancreaticoduodenectomy versus local resection in the treatment of gastrointestinal stromal tumors of the duodenum. World J Gastroenterol 2013, 11:196-201.

41. Demetri GD, VonMehren M, Antonescu CR, DeMatteo RP, Ganjoo KN, Maki RG, Pisters PW, Raut CP, Riedel RF, Schuetze S, Sundar HM, Trent JC, Wayne JD: NCCN task force report: Update on the management of patients with gastrointestinal stromal tumors. J Natl Compr Canc Net 2010, 8:S1-S41.

42. Demetri GD, Mehren von M, Blanke CD, Van den Abbeele AD, Eisemberg B, Roberts PJ, Heinrich MC, Tuveson DA, Singer S, Janicek M, Fletcher JA, Silverman SG, Silberman SL, Capdeville R, Kiese B, Peng B, Dimitrijevic S, Druker BJ, Corless C, Fletcher CD, Joensuu H: Efficacy and safety of Imatinib mesylate in advanced gastrointestinal stromal tumor. $N$ Engl J Med 2002, 347:472-480.

43. Demetri GD, Oosterom Van AT, Garrett CR, Blackstein ME, Shah MH, Verweij J, McArthur G, Judson IR, Heinrich MC, Morgan JA, Desai J, Fletcher CD, George S, Bello CL, Huang X, Baum CM, Casali PG: Efficacy and safety of Sunitinib in patients with advanced gastrointestinal stromal tumour after failure of Imatinib: a randomized controlled trial. Lancet 2006, 368:1329-1338.

44. Blanke CD, Rankin C, Demetri GD, Ryan CW, von Mehren M, Benjamin RS, Raymond AK, Bramwell VH, Baker LH, Maki RG, Tanaka M, Hecht JR, Heinrich MC, Fletcher CD, Crowley JJ, Borden EC: Phase III randomized, intergroup trial assessing imatinib mesylate at two dose levels in patients with unresectable or metastatic gastrointestinal stromal tumors expressing the kit receptor tyrosine kinase. S0033. J Clin Oncol 2008, 26:626-632.

45. Dematteo RP, Ballman KW, Antonescu CR, Maki RG, Pisters PW, Demetri GD, Blackstein ME, Blanke CD, von Mehren M, Brennan MF, Patel S, McCarter MD, Polikoff JA, Tan BR, Owzar K, American School of Surgeons Oncology Group (ACOSOG) Intergroup Adjuvant GIST Study Team: Adjuvant Imatinib mesylate after resection of localized, primary gastrointestinal stromal tumour: a randomized, dowble-blind, placebo-controlled trial. Lancet 2009, 373:1097-104

46. Dubreuil P, Letard S, Ciufolini M, Gros L, Humbert M, Castéran N, Borge L, Hajem B, Lermet A, Sippl W, Voisset E, Arock M, Auclair C, Leventhal PS, Mansfield CD, Moussy A, Hermine O: Masitinib (AB 1010) A potent and selective tyrosine Khinase inhibitor targeting Kit. PLoS One 2009, 4:e7258

47. Sawaki A, Nishida T, Doi T, Yamada Y, Komatsu Y, Kanda T, Kakeji Y, Onozawa Y, Yamasaki M, Ohtsu A: Phase 2 study of Nilotinib as third-line therapy for patients with gastrointestinal stromal tumor. Cancer 2011, 117:4633-4641.

48. Park SH, Ryu MH, Ryoo BY, Im SA, Kwon HC, Lee SS, Park SR, Kang BY, Kang YK: Sorafenib in patients with metastatic gastrointestinal stromal tumors who failed two or more prior tyrosine kinase inhibitors: a phase II study of Korean gastrointestinal stromal tumors study group. Invest New Drugs 2012, 30:2377-2383.
49. Joensuu H, Eriksson M, Sundby Hall K, Hartmann JT, Pink D, Schutte J, Ramadori G, Hohenberger P, Duyster J, Al-Batran SE, Schlemmer M, Bauer S, Wardelmann E, Sarlomo-Rikala M, Nilsson B, Sihto H, Monge OR, Bono P, Kallio R, Vehtari A, Leinonen M, Alvegard T, Reichardt P: One vs Three years of adjuvant Imatinib for operable gastrointestinal stromal tumor: a randomized trial. JAMA 2012, 307:1265-1272.

doi:10.1186/1477-7819-12-105

Cite this article as: Beltrame et al: Extra-gastrointestinal stromal tumor of the pancreas: case report and review of the literature. World Journal of Surgical Oncology 2014 12:105.

\section{Submit your next manuscript to BioMed Central and take full advantage of:}

- Convenient online submission

- Thorough peer review

- No space constraints or color figure charges

- Immediate publication on acceptance

- Inclusion in PubMed, CAS, Scopus and Google Scholar

- Research which is freely available for redistribution 